\title{
Developing anterior mediastinum mass after orthotopic thyroidectomy: a case report
}

\author{
Rita Meira Soares Camelo* and José Maria Barros
}

\begin{abstract}
Background: Ectopic thyroid tissue is a rare embryological aberration described by the occurrence of thyroid tissue at a site other than in its normal pretracheal location. Depending on the time of the disruption during embryogenesis, ectopic thyroid may occur at several positions from the base of the tongue to the thyroglossal duct. Ectopic mediastinal thyroid tissue is normally asymptomatic, but particularly after orthotopic thyroidectomy, it might turn out to be symptomatic. Symptoms are normally due to compression of adjacent structures.

Case presentation: We present a case of a 66-year-old male submitted to a total thyroidectomy 3 years ago, due to multinodular goiter (pathological results revealed nodular hyperplasia and no evidence of malignancy), under thyroid replacement therapy. Over the last year, he developed hoarseness, choking sensation in the chest, and shortness of breath. Thyroid markers were unremarkable. He was submitted to neck and thoracic computed tomography, magnetic resonance imaging, and radionuclide thyroid scan. Imaging results identified an anterior mediastinum solid lesion. A radionuclide thyroid scan confirmed the diagnosis of ectopic thyroid tissue. The patient refused surgery.
\end{abstract}

Conclusions: Ectopic thyroid tissue can occur either as the only detectable thyroid gland tissue or in addition to a normotopic thyroid gland. After a total thyroidectomy, thyroid-stimulating hormone can promote a compensatory volume growth of previously asymptomatic ectopic tissue. This can be particularly diagnosis challenging since ectopic tissue can arise as an ambiguous space-occupying lesion.

Keywords: Case report, Ectopic thyroid tissue, Mediastinal masses, Thyroid

\section{Background}

An anterior mediastinal mass may be asymptomatic and incidentally discovered on imaging examinations. It could origin compression or local invasion of nerves trunks (causing hoarseness pain, paralysis of the diaphragm or vocal cords), vascular structures (causing superior vena cava syndrome), airways (causing dyspnea, cough), esophagus (causing dysphagia), and bone [1].

The main differential diagnosis of a space occupying lesion at the anterior mediastinum, includes thymic

\footnotetext{
*Correspondence: ritameiracamelo@gmail.com

Hospital de São José - Centro Hospitalar Universitário Lisboa Central, Lisboa,
}

(c) The Author(s). 2020 Open Access This article is licensed under a Creative Commons Attribution 4.0 International License, which permits use, sharing, adaptation, distribution and reproduction in any medium or format, as long as you give appropriate credit to the original author(s) and the source, provide a link to the Creative Commons licence, and indicate if changes were made. The images or other third party material in this article are included in the article's Creative Commons licence, unless indicated otherwise in a credit line to the material. If material is not included in the article's Creative Commons licence and your intended use is not permitted by statutory regulation or exceeds the permitted use, you will need to obtain permission directly from the copyright holder. To view a copy of this licence, visit http://creativecommons.org/licenses/by/4.0/. toma), and thyroid lesions including goiter $[1,2]$.

Ectopic thyroid tissue (ETT) is a rare embryological aberration described by the occurrence of thyroid tissue at a site other than in its normal pretracheal location. It comprises approximately $1 \%$ of mediastinal tumors [2].

The thyroid develops as an endodermal bud from the anterior floor of the pharynx and descends down on either side of the trachea to its pretracheal location, where it merges with the caudal prolongation of the fourth pharyngeal pouch to form the thyroid gland. Depending on the time of the disruption during embryogenesis, ectopic thyroid may occur at several positions from the base of the tongue to the thyroglossal duct $[3,4]$.
Hospital de São José - Centro Hospi
Portugal
Springer Open 
Mediastinal thyroid tissue has occasionally been reported to arise from a displacement of the thyroid remnants into the mediastinum with the heart as it migrates downward.

Ectopic thyroid gland tissue can occur either as the only detectable thyroid gland tissue or in addition to a normotopic thyroid gland. After a total thyroidectomy, thyroid-stimulating hormone can promote a compensatory volume growth of previously asymptomatic ectopic tissue. This ectopic tissue can arise as an ambiguous space-occupying lesion [5].

Ectopic mediastinal thyroid tissue is normally asymptomatic, but particularly after orthotopic thyroidectomy it might turn out to be symptomatic. Symptoms are normally due to compression of adjacent structures $[5,6]$.

CT (computed tomography) and MRI (magnetic resonance imaging) findings of an ectopic mediastinal thyroid are not specific. However, its enhancement characteristics and morphological features are similar to the normal thyroid tissue in the pretracheal location, which, in suspicious cases, may be a clue to the diagnosis. A radionuclide thyroid scan can confirm the diagnosis.

Commonly, malignant transformation in ETT is rare [7]. However, these lesions must be resected surgically due to the risks of malignant transformation, gradual enlargement, and risk of hemorrhage within the mass. If the patient refuses surgery, regular imaging monitoring is recommended in order to identify initial signs or symptoms of thyroid dysfunction or malignant transformation [8].

\section{Case presentation}

We present a case of a 66-year-old male submitted to a total thyroidectomy 3 years ago, due to multinodular goiter (pathological results revealed nodular hyperplasia and no evidence of malignancy), under thyroid replacement therapy. Over the last year, he developed hoarseness, choking sensation in the chest, and shortness of breath. Thyroid markers were unremarkable. He was submitted to a neck and thoracic CT, MRI, and radionuclide thyroid scan.

Imaging findings demonstrated an absent orthotopic thyroid gland, consistent with the history of total thyroidectomy. CT scan (Fig. 1) imaging revealed a wellcircumscribed, homogeneously enhancing tissue, showing some calcifications, at the level of the anterior mediastinum, at pre-vascular space, measuring $49 \times 25 \mathrm{~mm}$.

MRI (Fig. 2, Fig. 3), demonstrated a heterogeneous lesion, with well-defined margins and regular contour, with heterogeneous hypointensity signal on T1 weighted images (WI), and slightly heterogeneous with areas of low and high signal intensity on T2WI. Small punctate foci of low signal intensity were seen on both $\mathrm{T} 1$ and T2WI sequences due to microcalcifications. The lesion

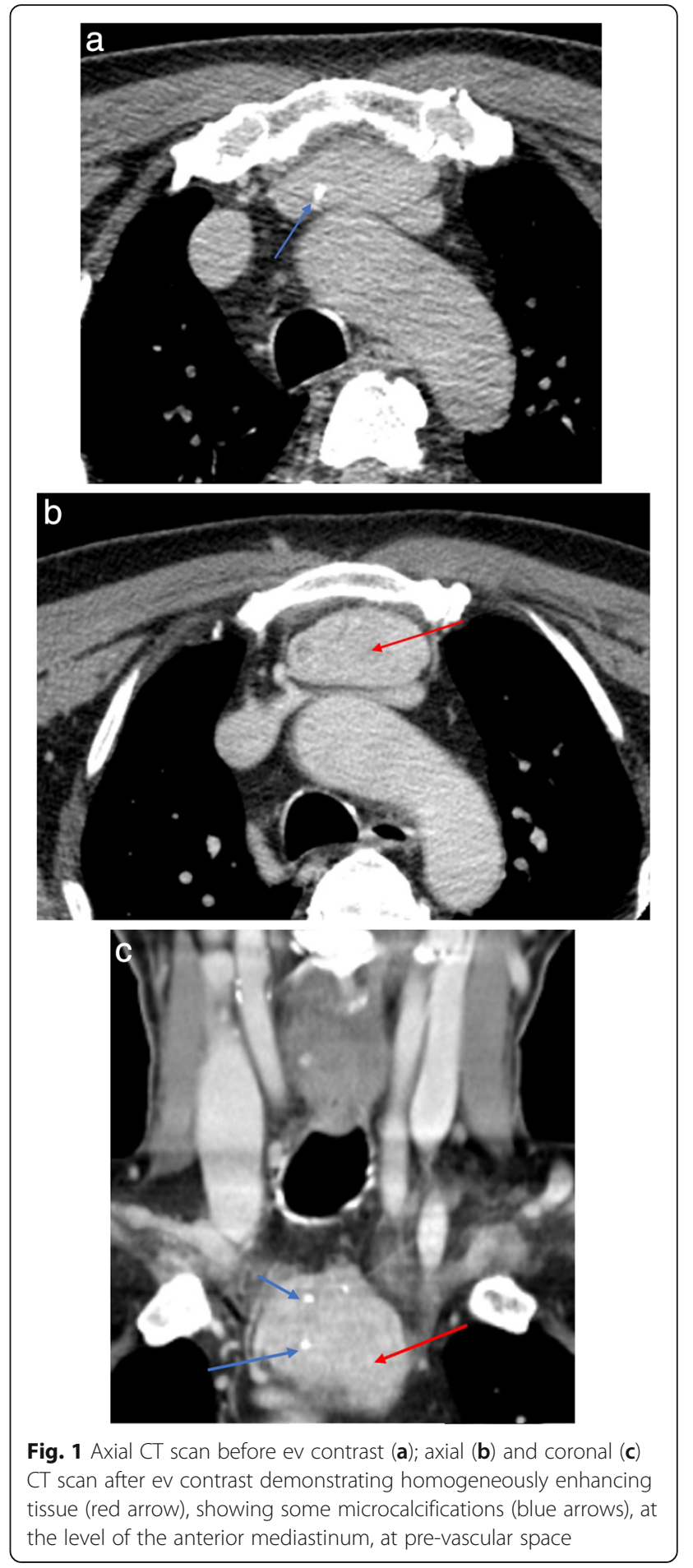

was well demarcated from the adjacent mediastinal structures, with slightly displacing of the left venous brachiocephalic trunk. No restriction to diffusion was observed.

The lesion demonstrated avid and progressive enhancement. 

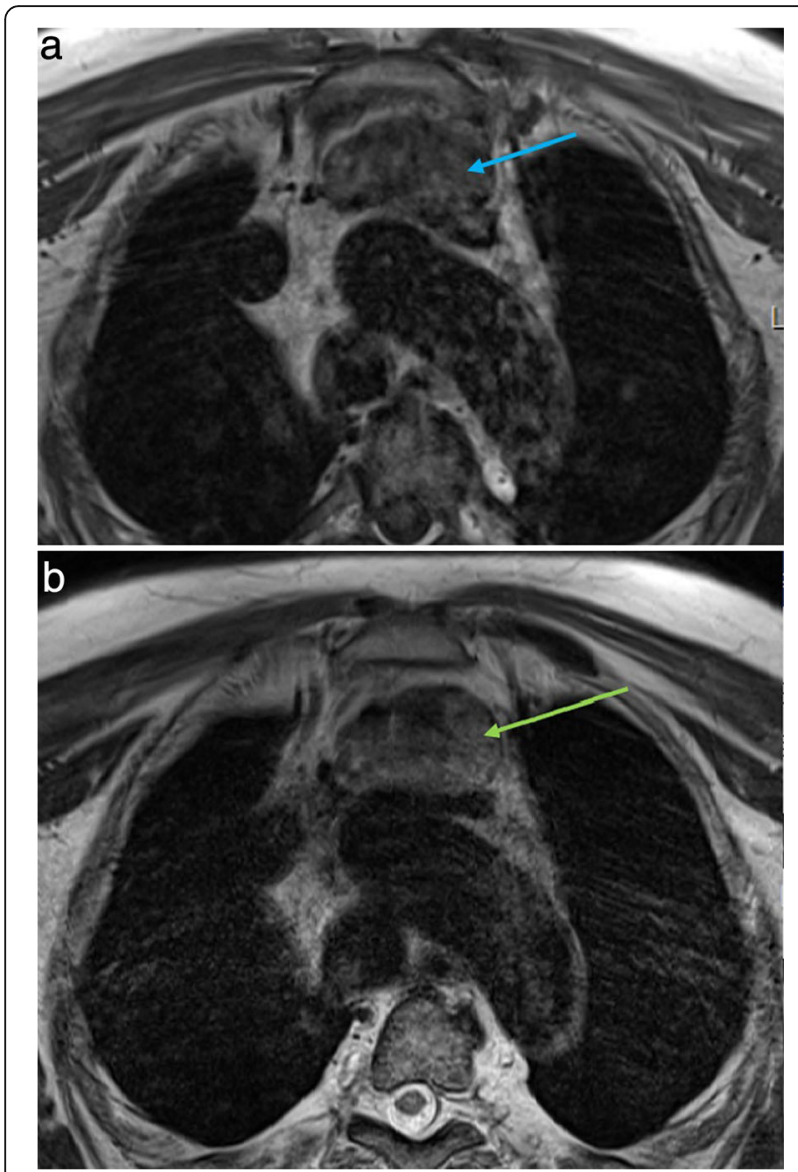

Fig. 2 Axial T1 (a) and T2WI (b) demonstrating heterogeneous anterior mediastinal mass, with well-defined margins and regular contour, with heterogeneous hypointensity signal on T1WI (blue arrow), and heterogeneous with areas of low and high signal intensity on T2WI (green arrow)

Given the patient's history, these findings were suggestive of developing mediastinal ectopic thyroid mass after orthotopic thyroidectomy, compressing the laryngeal nerve. Scintigraphy was performed (Fig. 4), showing ectopic functioning thyroid tissue at anterior mediastinum. The patient refused surgery; therefore, imaging surveillance will be implemented.

\section{Conclusions}

Ectopic thyroid tissue is a rare entity, and can be challenging to diagnose. Differentiating this entity from other mediastinal masses is particularly important since the diagnosis affects management and outcome.

Benign mediastinal ETTs are usually asymptomatic and are found incidentally. Surgical intervention should always be considered in the course of diagnosing the nature of the mediastinal mass even in elderly patients. This is because of the high risk of tracheal compression and the low morbidity of the surgery $[9,10]$.
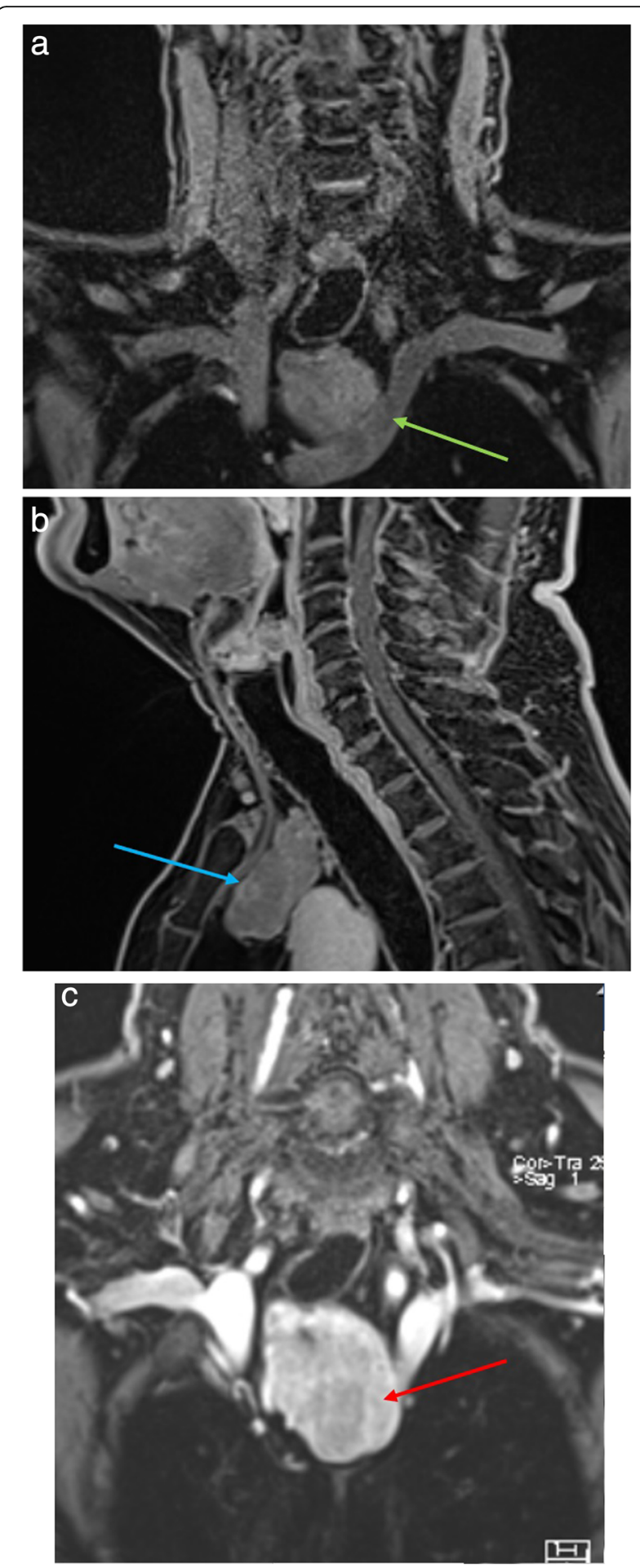

Fig. 3 Coronal T1 Dixon (a); Sagittal T1 Vibe Dixon (b) and coronal T1 after gadolinium (c) demonstrating a well-circumscribed, heterogeneously enhancing tissue (red arrow), at the level of the anterior mediastinum, at pre-vascular space (blue arrow). The lesion is well demarcated from the adjacent mediastinal structures, with slightly displacing and compression of left venous brachiocephalic trunk (green arrow) 


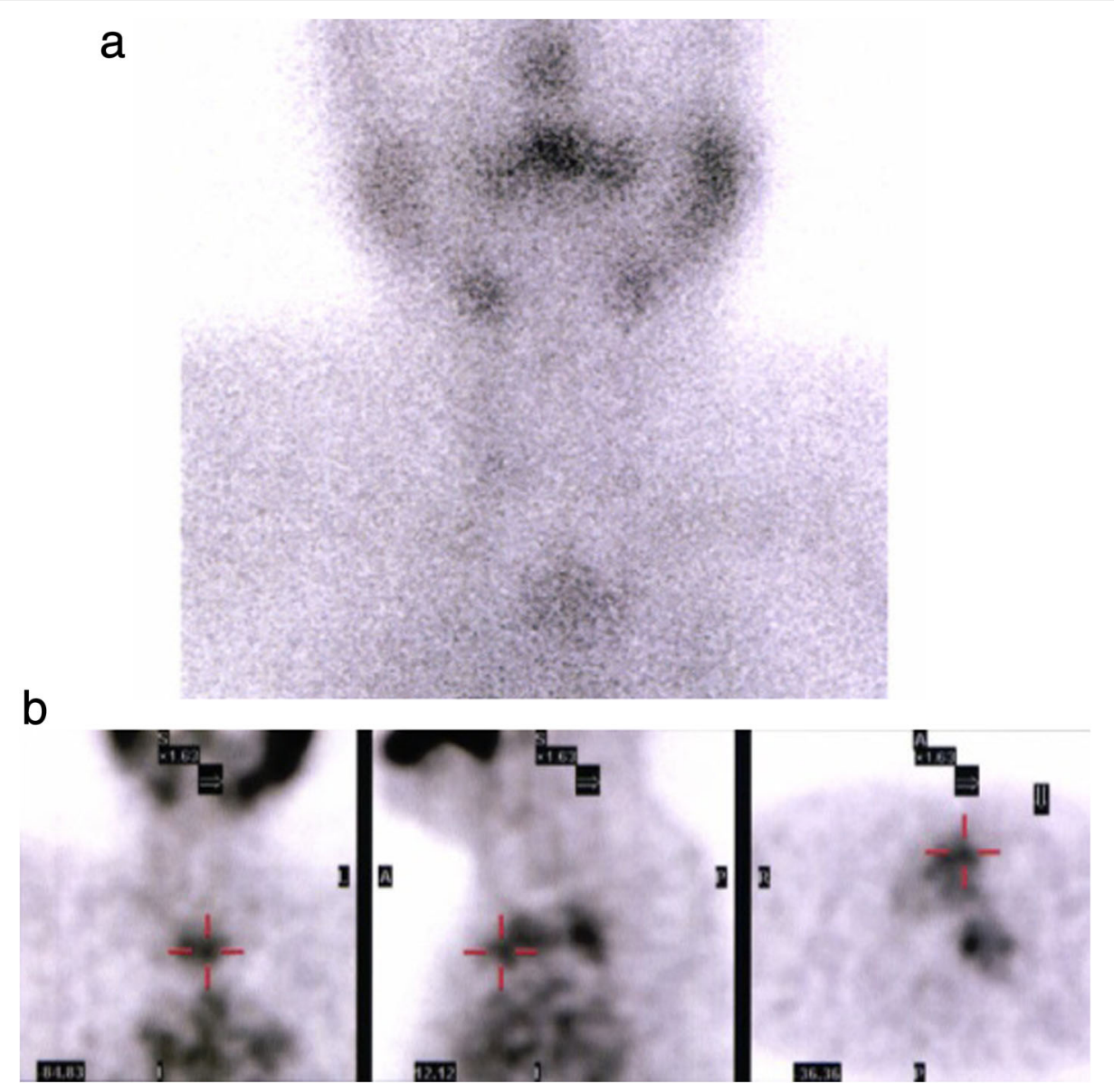

Fig. 4 a, b Radionuclide thyroid scan demonstrating mediastinal anterior functioning thyroid tissue

Surgical excision of mediastinal masses is done either through thoracotomy or sternotomy according to the location of the mass [11].

Main differential diagnoses of anterior mediastinal mass includes thymic tumors, lymphomas and dermoid cysts.

Ectopic mediastinal thyroid tissue should be considered when an anterior mediastinal lesion is identified, particularly when developed after orthotopic thyroidectomy.

\section{Abbreviations}

$\mathrm{CT}$ : Computed tomography; MRI: Magnetic resonance imaging; ETT: Ectopic thyroid tissue; Wl: Weighted image

\section{Acknowledgements}

Not applicable

\section{Authors' contributions}

$\mathrm{RC}$ reviewed the available literature and drafted the manuscript. JMB provided clinical information and medical images, as well as critically revised the manuscript. The authors read and approved the final version of the manuscript.

\section{Funding}

The authors declare that there were no external sources of study for the performance of this article.
Availability of data and materials

The datasets used and/or analyzed during the current study are available from the corresponding author on reasonable request.

\section{Ethics approval and consent to participate}

Ethical approval is not required for the publication of isolated case reports. The patient was informed about the procedure, and a written informed consent was obtained.

Consent for publication.

Written informed consent was obtained from the patient for publication of this case report and accompanying images.

\section{Competing interests}

All authors declare no competing interests.

Received: 29 September 2020 Accepted: 30 November 2020

Published online: 08 December 2020

\section{References}

1. Shahrzad M, Le Mai T, Silva M, Bankier A (2014) Anterior Mediastinal Masses American Journal of Roentgenology 203:128-138

2. Sakorafas GH, Vlachos A, Tolumis G, Kassaras GA, Anagnostopoulos GK, Gorgogiannis D (2004) Ectopic intrathoracic thyroid: case report. Mt Sinai J Med 71(2):131-133

3. Tang AT, Johnson MJ, Addis B, Weeden DF (2002) Thoracic intrathymic thyroid and cervical goiter: single-stage resection. Ann Thorac Surg 74(5): 578-579

4. Williams RJ, Lindop G, Butler J (2002) Ectopic thyroid tissue on the ascending aorta: an operative finding. Ann Thorac Surg 73(5):1642-1643 
5. Seitz D, Todt I, Boga E, Yasin A (2020) Sudhoff H, Ectopic thyroid tissue after total thyroidectomy. HNO 68(6):447-450. https://doi.org/10.1007/s00106019-00754-7

6. Fewins J, Simpson CB, Miller FR (2003) Complications of thyroid and parathyroid surgery. Otolaryngol Clin North Am 36:189-206

7. Shah BC, Ravichand CS, Juluri S, Agarwal A, Pramesh CS, Mistry RC (2007) Ectopic thyroid cancer. Ann Thorac Cardiovasc Surg 13(2):122-124

8. Mohamed A, Scheer F, Andresen R (2015) Ectopic Mediastinal Thyroid Tissue With a Normally Located Thyroid Gland. Iran J Radiol 2(1):e7054 https://doi.org/10.5812/iranjradiol.7054

9. Choudhury BK, Saikia UK (2011) Dual ectopic thyroid with normally located thyroid: a case report. J Thyroid Res 2011:159703

10. Toso A, Colombani F, Averono G, Aluffi P, Pia F (2009) Lingual thyroid causing dysphagia and dyspnoea. Case reports and review of the literature. ActaOtorhinolaryngolltal 29:213-217

11. Noussios G, Anagnostis P, Goulis DG, Lappas D, Natsis K (2011) Ectopic thyroid tissue anatomical clinical and surgical implications of a rare entity. Eur J Endocrinol 165:375-382

\section{Publisher's Note}

Springer Nature remains neutral with regard to jurisdictional claims in published maps and institutional affiliations.

\section{Submit your manuscript to a SpringerOpen ${ }^{\circ}$ journal and benefit from:}

- Convenient online submission

- Rigorous peer review

- Open access: articles freely available online

- High visibility within the field

- Retaining the copyright to your article

Submit your next manuscript at $\boldsymbol{\nabla}$ springeropen.com 